\title{
高出力ファイバグレーテイングレーザーの作製とその特性
}

\author{
那須 秀行 , 鈴木 薰* , 青木 典之** \\ 古河電気工業 (株) 横浜研究所 (テ220-0073 神奈川県横浜市西区岡野2-4-3) \\ *日本大学 理工学部電気工学科 ( 1 101-8308 東京都千代田区神田駿河台1-8-14) \\ **東京電力 (株) システム研究所 (テ230-8510 神奈川県横浜市鶴見区江ヶ崎町4-1)
}

\section{Fabrication of High-Power Fiber Grating Laser and Its Performance}

\author{
Hideyuki NASU, Kaoru SUZUKI,* and Noriyuki AOKI** \\ Yokohama R\&D Laboratories, The Furukawa Electric Co., Ltd. \\ 2-4-3 Okano, Nishi-ku, Yokohama, Kanagawa 220-0073 \\ *Electrical Engineering, College of Science and Technology, Nihon University \\ 1-8-14 Surugadai, Kanda, Chiyoda, Tokyo 101-8308 \\ **Computer \& Communication R\&D Center, Tokyo Electric Power Company \\ 4-1 Egasaki, Tsurumi-ku, Yokohama, Kanagawa 230-8510
}

(Received October 21, 1999)

\begin{abstract}
We theoretically considered suitable configurations of a fiber grating laser (FGL) to be used in wavelength division multiplexing (WDM) systems. We focused on the effect of composite reflectors where the effect of the front facet of a semiconductor optical amplifier (SOA) is especially significant. We simulated relaxation oscillation frequency and optical power to determine a configuration enabling high bit rates, up to $2.5 \mathrm{Gbit} / \mathrm{s}$. After arriving at a suitable configuration, a packaged FGL has been fabricated. This laser achieves higher output power than any previously reported, and the potential for a rate of $2.5 \mathrm{Gbit} / \mathrm{s}$ was confirmed. Compared with a typical $1.55 \mu \mathrm{m}$ MQW DFB laser, the lasing wavelength temperature dependence is less than half that of a DFB laser. As frequency chirping is remarkably reduced, the power penalty of the FGL is 3 times smaller than that of a DFB laser in transmission experiment with SMF of $70 \mathrm{~km}$.
\end{abstract}

Key Words: Fiber grating laser (FGL), Fiber grating (FG), Wavelength division multiplexing (WDM), Semiconductor optical amplifier (SOA)

\section{1.はじめに}

ファイバグレーティングレーザー (FGL: fiber grating laser) は, 外部分布反射器であるファイバグレーティング (FG: fiber grating) 1,2)のブラッグ波長を選別することで, 発 振波長を規定できるため, 高密度波長分割多重(DWDM: dense wavelength division multiplexing) システムにおける有 望な光源として検討が進められている。これまでにFGLを 直接変調し, $2.5 \mathrm{Gbit} / \mathrm{s}^{3)}, 2.6 \mathrm{Gbit} / \mathrm{s}^{4)}$ 及び $10 \mathrm{Gbit} / \mathrm{s}^{5,6)}$ という高 速ビットレートによる伝送実験の報告がある．FGLは波長 選択が容易であるという利点の他に, $\mathrm{Q}$ 值の高い共振器を 構成することにより線幅及びチャーピングが狭い7,8) とい う利点もあり, 幹線系DWDMシステムへの適用が期待され ている。

FGLは外部共振器構造である故, 所望のレーザーの特性 が得られるように各構成要素を設計する必要がある。ま ず半導体光増幅器 (SOA: semiconductor optical amplifier) 前 端面と光結合系とFGによって構成される複合反射面の特
性を明らかにする必要がある，特にSOA前端面には, 無反 射 (AR: anti-reflection) コーティングが必要不可欠であり， 10-4以下の反射率が望ましいことが示唆されている9 が, そ の反射率の影響については明らかにされていない. 本報 告では, まずこの複合反射面の特性について検討し, レー ザーの発振特性への影響について考察した。次に, 実際に 送信器に適用するためには, 所望の光出力と所望の伝送速 度を同時に実現する必要があり,これに見合う特性を有す FGLを設計しなければならない。伝送速度は緩和振動周波 数に依存しており,これはSOA長, グレーティング位置, グ レーティング長さで決まる共振器長に支配されている. それ故, 所望な緩和振動周波数が得られるように構成を設 計出来る指標が求められる。 そこで我々はグレーティン グの有効長10) を用いて実効共振器長を求め, 緩和振動周波 数と光出力への影響を検討し,特に長距離伝送システムへ の適用を目的として高出力化の観点から最適な構成を導 いた。

これらの設計指針を反映させてFGLを作製した ${ }^{11,12)}$ 。そ 
して, 従来の光源であるDFB (distributed feed back) レーザー と比較しつつ, 光信号送信用光源としての特性を明らかに し, 光情報通信システムへの適用可能性について検討を 行ったので報告する.

\section{FGLの構成検討}

\section{1 複合反射面の検討}

FGLは高反射 (HR: high-reflection) 面とAR面を有すSOA とファイバ端面がレンズ化されたFGからなる。Fig.1は FGLの構成図である。FGL, 共振器内に屈折率と長さの 異なる境界を有し, 各境界にて反射率を持つ複合共振器を 有す。各々の領域における屈折率, 長さ, 反射率を図中に 示した. $C_{\mathrm{out}}$ は光結合係数である. 波長選択性反射器であ るFGの電界反射率 $r_{\mathrm{g}}$ は次のように表される。

$$
\begin{aligned}
& r_{\mathrm{g}}=\frac{-\mathrm{j} \kappa \tanh \left(\gamma L_{\mathrm{s}}\right)}{\gamma+\left(\frac{\alpha_{\mathrm{g}}}{2}+\mathrm{j} \delta\right)^{2} \tanh \left(\gamma_{\mathrm{g}}\right)}=\left|r_{\mathrm{g}}\right| \exp (-\mathrm{j} \phi) \\
& \kappa=\frac{\pi \Delta n}{\lambda}, \quad \gamma^{2}=\left(\frac{\alpha_{\mathrm{g}}}{2}+\mathrm{j} \delta\right)^{2}+\kappa^{2}, \\
& \delta=2 n_{4} \pi\left(\frac{1}{\lambda}-\frac{1}{\lambda_{\mathrm{B}}}\right)
\end{aligned}
$$

ここで㠹電界反射の位相, $\alpha_{\mathrm{g}}$ は,ファイバコアにおける 吸収や回折による損失である。 $\Delta n$ は屈折率変化, $\lambda_{\mathrm{B}}$ はブ ラッグ波長である。複合共振器の取り扱いを容易にする ために, $\mathrm{SOA}$ 前面からみた場合の複合反射率を $r_{\mathrm{com}}$ と定義 すると, $r_{\mathrm{com}}$ は等価的にSOAの前端面において反射率及び 反射位相を持った反射面として考えることが出来る．各 領域における光波の伝搬, 反射及び透過, 結合を行列で表 し, それぞれを $\Phi_{\mathrm{i}}, M_{\mathrm{ij}}, C$ と各々定義すると，

$$
\begin{aligned}
& {\left[\begin{array}{c}
E_{5}^{+}\left(z_{5}\right) \\
0
\end{array}\right]=M_{34} \Phi_{4} M_{32} C \Phi_{2} M_{21}\left[\begin{array}{l}
E_{1}^{+}\left(z_{2}\right) \\
E_{1}^{-}\left(z_{2}\right)
\end{array}\right]} \\
& =T\left[\begin{array}{c}
E_{1}^{+}\left(z_{2}\right) \\
E_{1}^{-}\left(z_{2}\right)
\end{array}\right]
\end{aligned}
$$

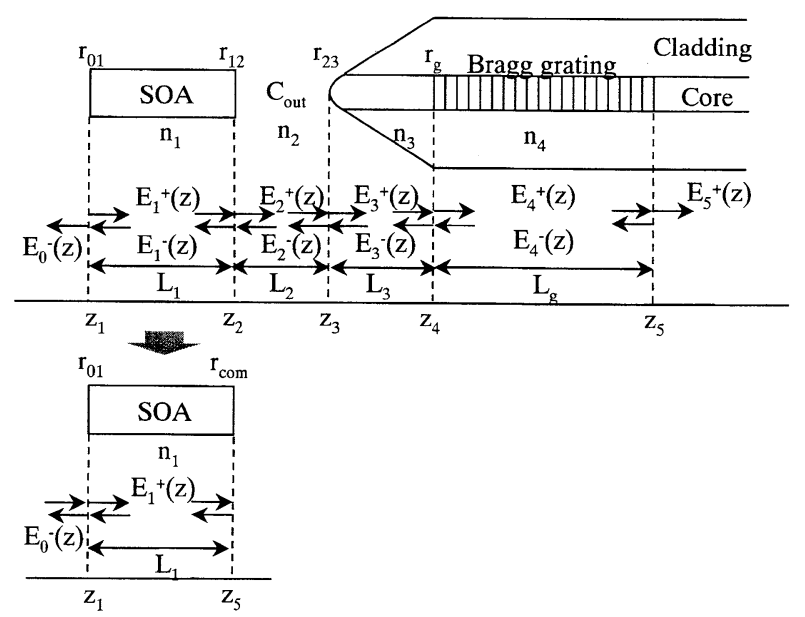

Fig.1 Illustration of FGL and its compound cavity model.
と表されるから, 複合反射率 $r_{\mathrm{com}}$ と複合透過率 $t_{\mathrm{com}}$ は次のよ うに表すことが出来る.

$$
E_{5}^{+}\left(z_{5}\right)=\frac{T_{11} T_{22}-T_{12} T_{21}}{T_{22}} E_{1}^{+}\left(z_{2}\right) \equiv t_{\mathrm{com}} E_{1}^{+}\left(z_{2}\right)
$$

$$
E_{5}^{+}\left(z_{5}\right)=-\frac{T_{21}}{T_{22}} E_{1}^{+}\left(z_{2}\right) \equiv r_{\text {com }} E_{1}^{+}\left(z_{2}\right)
$$

次に, 複合反射面の特性を考えるに当たり, 電界反射率 よりもパワー反射率の方が実測結果と比較でき, 理解が容 易であるので複合反射面のパワー反射率 $R_{\mathrm{com}}$ を計算する. $R_{\mathrm{com}}$ は, 複素反射率であるからパワー反射の位相 $\varphi$ を用い て,次のように表される。

$$
R_{\text {com }}=\left|R_{\text {com }}\right| \exp (-\mathrm{j} \varphi)
$$

計算では, 次のような仮定を行った。レンズドファイバ による結合系では $L_{2}$ は波長の数倍程度の長さとなり, 実験 では $L_{2}=10 \mu \mathrm{m}$ の時, 結合効率 $\eta\left(=C_{\text {out }}{ }^{2}\right)$ が最大となるので, $L_{2}=10 \mu \mathrm{m}, \eta=0.5$ とした. レンズドファイバ端面の反射 率 $R_{23}$ には, 実際に作製した時の測定結果から $R_{23}=7 \times 10^{-5}$ とした．屈折率は $n_{2}=1, n_{3}=n_{\mathrm{g}}=1.47$ とした， $r_{\mathrm{g}}$ は次の様 に条件を与えて求めた。 まず $\lambda=\lambda_{\mathrm{B}}$ におけるパワー反射率 の振幅 $\left|R_{\mathrm{g}}\right|$ と半值全幅 $\Delta \lambda$ を与えておき, 次に $\Delta n$ と $L_{\mathrm{g}}$ を求め, 任意のFGの反射特性を得た. $\lambda_{\mathrm{B}}=1550 \mathrm{~nm},\left|R_{\mathrm{g}}\right|=0.3, \Delta \lambda=$ $0.2 \mathrm{~nm}$ とした. グレーティングの位置を $\mu \mathrm{m}$ オーダの精度で 作り込むことは困難であり, $L_{3}$ はせいぜい $0.1 \mathrm{~mm}$ 程度の精 度が限界である。 そこで, $L_{3}$ と $\lambda=\lambda_{\mathrm{B}}$ における $\left|R_{\mathrm{com}}\right|$ の関係 を $R_{12}$ をパラメータとして計算した。 その結果をFig.2に示 す. $\left|R_{\mathrm{com}}\right|$ は $L_{3} に$ 依存して周期的に変化し, その周期は, $0.5 \mu \mathrm{m}$ 程度である.このように, 発振波長よりも短い長さ の $L_{3}$ に依存して $\left|R_{\mathrm{com}}\right|$ は共振特性を持ち変動する。図中に

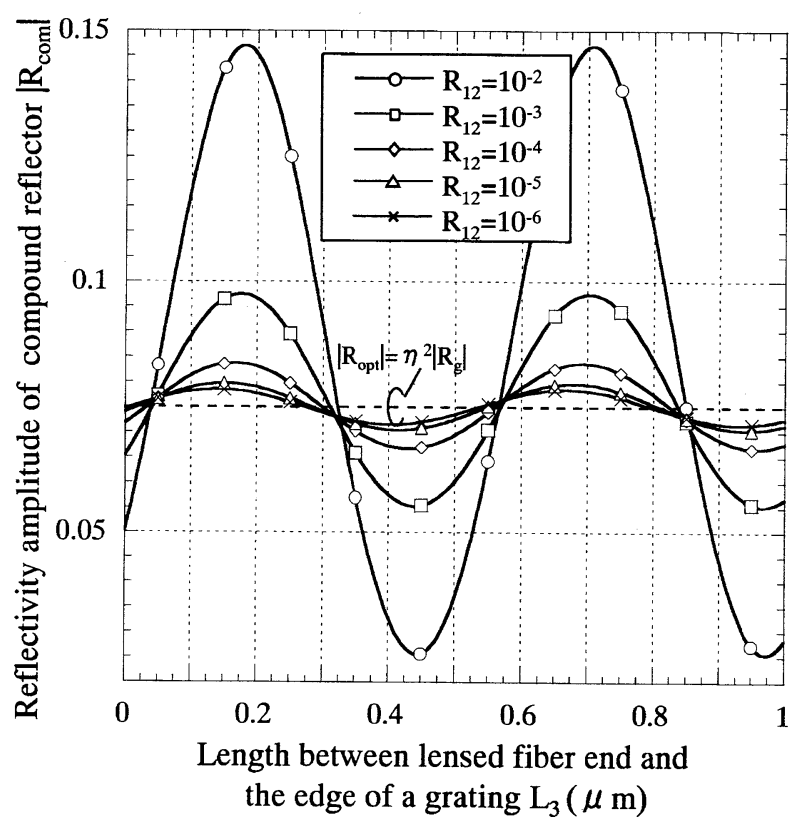

Fig.2 Reflectivity amplitude of compound reflector $\left(\left|R_{\text {com }}\right|\right)$ as a function of length between lensed fiber end and the edge of Bragg grating $\left(L_{3}\right)$ where a parameter is AR facet reflectivity $\left(R_{12}\right)$. 


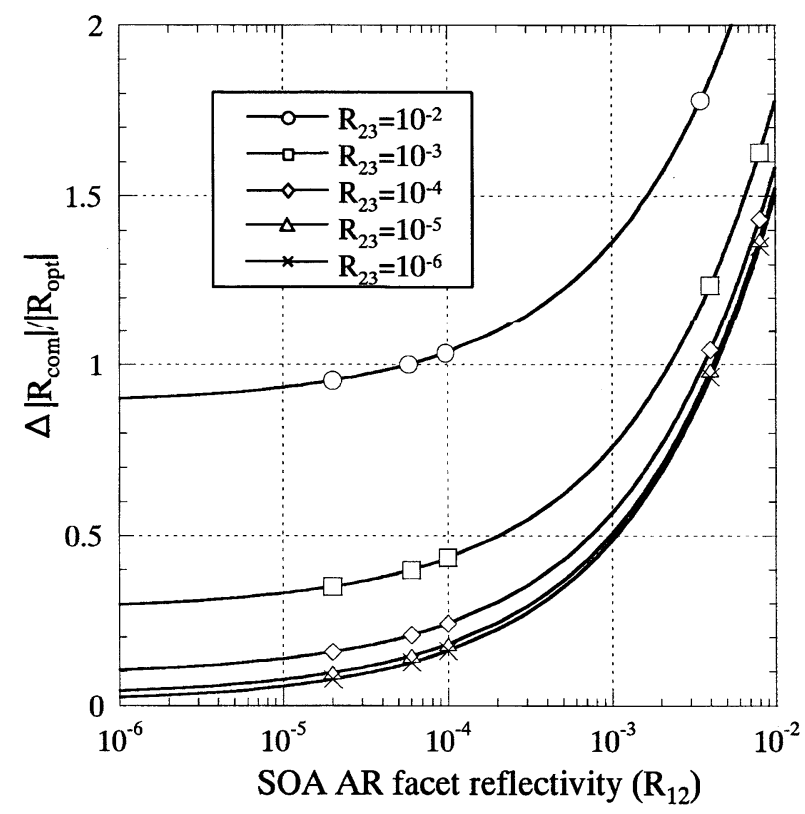

Fig.3 Relation between $\left|R_{\text {com }}\right| /\left|R_{\text {opt }}\right|$ and AR facet reflectivity $\left(R_{12}\right)$.

示した $\left|R_{\mathrm{opt}}\right|$ は $R_{12}=R_{23}=0$ の場合の $\left|R_{\mathrm{com}}\right|$ であり, 複合反射 が抑圧され, $\left|R_{\mathrm{opt}}\right|=\eta^{2}\left|R_{\mathrm{g}}\right|$ と一定值となる．変動幅は, $R_{23}$

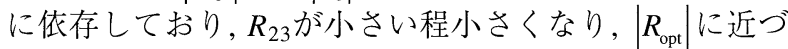
く. 次に $\left|R_{\mathrm{com}}\right|$ の変動幅を $\Delta\left|R_{\mathrm{com}}\right|$ と定義し, $R_{12}$ と $R_{23}$ による 影響を検討した. Fig.3に $R_{12}$ と $\Delta\left|R_{\mathrm{com}}\right| /\left|R_{\mathrm{opt}}\right|$ の関係を示す. パラメー夕は $R_{23}$ である. $\Delta\left|R_{\mathrm{com}}\right|$ が大きい程, しきい電流, 光出力の変化が大きくなり, 不安定要因となる. 複合反射 面の共振を抑圧するためには, $R_{12}, R_{23}$ 共に小さい程良い. しかしながら, ARコーティングによって実現できる反射率 には限界がある． $R_{12}$ は $10^{-4}$ と $10^{-3}$ の間で傾きが大きく変化 しており, $R_{12} \leqq 10^{-4}$ では $\Delta\left|R_{\mathrm{com}}\right| /\left|R_{\mathrm{opt}}\right|$ はほとんど変わらな い. $R_{23} \leqq 10^{-4}$ においても $\Delta\left|R_{\mathrm{com}}\right| /\left|R_{\mathrm{opt}}\right|$ はほとんど変わらな い. 従って, 複合反射面の共振特性を抑圧するための指標 は, $R_{12}, R_{23}$ ともに $10^{-4}$ 程度であることが判る.

\section{2 緩和振動周波数に関する検討}

伝送速度の限界は緩和振動周波数 $\left(f_{\mathrm{r}}\right)$ を指標にして見積 もることができる． $f_{\mathrm{r}}$ は共振器の光子寿命 $\tau_{\mathrm{p}}$ に依存する. FGLの実効共振器長 $L_{\text {cavity }}$ は, 次のように表すことが出来 る.

$$
L_{\text {cavity }}=n_{1} L_{1}+n_{2} L_{2}+n_{3} L_{3}+n_{4} L_{\text {eff }}
$$

ここで, $L_{\mathrm{eff}}$ はグレーティング有効長 ${ }^{10)}$ である。 $L_{\mathrm{eff}}$ を用い れば,グレーティングを集中的な反射器として表現できる ので便利である．SOAのHR面とグレーティングの間を伝 搬する光子寿命 $\tau_{\mathrm{p}}$ は平均群速度 $v_{\mathrm{g}}$ の逆数として求められ る。

$$
=\frac{\tau_{\mathrm{p}}=1 / v_{\mathrm{g}}}{c\left\{\alpha_{1} L_{1}+\alpha_{2} L_{2}+\alpha_{3} L_{3}+\alpha_{4} L_{\text {eff }}+\ln \left(\frac{1}{t_{12}^{2} t_{23}^{2} C_{\text {out }}^{2} r_{01}\left|r_{\mathrm{g}}\right|}\right)\right\}}
$$

となる。 $\alpha_{\mathrm{i}}$ は各領域における損失係数, $t_{\mathrm{ij}}$ は, 各境界の電界 反射率, c は真空中の光速である。ここで, $f_{\mathrm{r}} \propto\left(1 / \tau_{\mathrm{p}}\right)^{-1 / 2}$ の関 係があるので, $f_{\mathrm{r}}$ は $L_{\text {cavity }}$ が長い程低くなり, 伝送速度が制限 される. 光信号を長距離伝送するには, 光源の出力が高い 方が有利である. 高出力を実現するには $L_{1}$ を長くすること が望ましいが, $\tau_{\mathrm{p}}$ が長くなる故, $f_{\mathrm{r}}$ が低くなる.

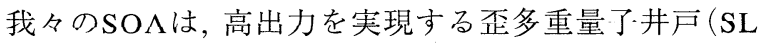
MQW: strained-layer multiple quantum well) 構造を用いてい

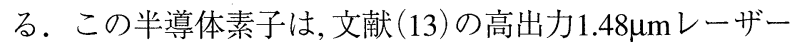
と同じ構造であり,同じプロセスで作製された．ただし,利 得帯域を $1.55 \mu \mathrm{m}$ 帯に移動させるために, 多重量子井戸層の 厚さを調整している，緩和振動周波数を低くするには， $L_{\text {cavity }}$ を短くする方が良いが, 高出力を得るには $L_{1}$ を長くす る方が良い, そこで, $L_{1}=600 \mu \mathrm{m}$ と $L_{1}=300 \mu \mathrm{m}$ のSOAを用 いる構成を想定して計算を行った. Fig.4は $L_{3}$ に対する $\tau_{\mathrm{p}}$ と 微小信号近似の $f_{\mathrm{r}}$ の関係である. $\eta=0.5, R_{01}=0.9$ とした. $\mathrm{FG}$ の特性は $\left|R_{\mathrm{g}}\right|=0.2, \Delta \lambda=0.1 \mathrm{~nm}, \lambda_{\mathrm{B}}=1.5 \mu \mathrm{m}$ である. 定義 したFGの反射特性となる $L_{\mathrm{g}}$ と $\Delta n$ を求め, これらから $L_{\mathrm{eff}}$ が 計算でき, $L_{\mathrm{eff}}=3.5 \mathrm{~mm}$ となる. ファイバ及び空気中の損失 が無く,レンズ端面及びSOA前端面は十分にARコーティン グされているものとした。

$L_{1}=600 \mu \mathrm{m}$ における $f_{\mathrm{r}}$ は, $L_{1}=300 \mu \mathrm{m}$ の場合と比較して $0.5 \mathrm{GHz}$ 低くなる程度である. 緩和振動周波数は $L_{2} に も 大$ きく依存し, $10 \mathrm{~mm}$ 程度で周波数は半分程度となる.

従って, 高出力かつ $2.5 \mathrm{Gbit} / \mathrm{s}$ の高速変調が可能となる FGLを実現するには $L_{1}=600 \mu \mathrm{m}$ し,$L_{2}$ をできるだけ短く するように工夫する必要がある。

\section{FGLの作製}

$L_{1}=600 \mu \mathrm{m}$ のSOAを用いて2.2章で定義した条件でFGL を作製した。また複合反射面の共振特性を抑圧するため

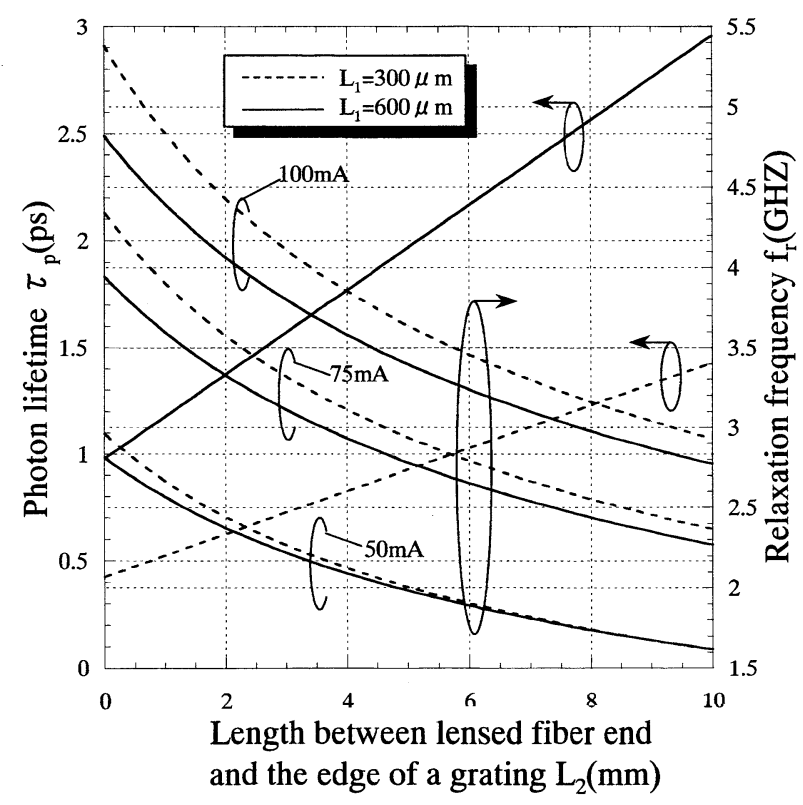

Fig.4 Simulated photon lifetime $\left(\tau_{\mathrm{p}}\right)$ and relaxation oscillation frequency $\left(f_{\mathrm{r}}\right)$ as a function of length between lensed fiber end and the edge of a grating $\left(L_{3}\right)$. 
に, $R_{12}$ 及び $R_{23}$ ともに $10^{-4}$ 以下となるようにARコーティン グを施した。 また, レンズ加工の過程を工夫して $L_{3}=0.1$ $\mathrm{mm}$ と短くした，光結合効率 $\eta$ は, ミラー損失のパラメータ であり, 発振特性に寄与する，従って，しきい電流を低く するには, $\eta$ は高いほど良い.ファイバとSOAの位置関係 には, 結合効率が最高となる最適点が存在し,この位置関 係からずれると $\eta$ は低下するので, 高い精度で光軸を調整 し, 固定する必要がある。作製したSOAのFFP(far field

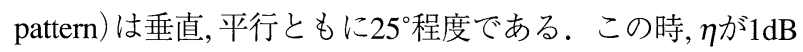
劣化となる光軸の垂直面におけるずれは, $\pm 0.6 \mu \mathrm{m}$, 平行方 向では, $\pm 2 \mu \mathrm{m}$ 程度となった。モジュールを組み立てた結 果, $\eta=0.5$ が得られた. SOAとファイバは, 同一のペルチェ 素子の上に組み立てられており, 温度制御が可能である。

\section{FGLの特性}

\subsection{I-L 特性と緩和振動周波数}

温度を $25^{\circ} \mathrm{C}$ 一定にし, FGLのファイバ出力 $\left(P_{\text {out }}\right)$ と $f_{\mathrm{r}}$ 測 定した.この結果をFig.5に示す.ファイバ出力は, FGLモ ジュールに接続したインライン型の光アイソレータ通過 後の光出力である. 高出力化のために, $\left|R_{\mathrm{g}}\right|$ を比較的小さ くしたため, 光コネクタからの反射戻り光により発振特性 が劣化する場合がある. 光アイソレータを接続すること で, 安定な発振特性を得ることができた.アイソレータの 挿入損失は $1 \mathrm{~dB}$ である。測定結果は, 計算結果と良く一致 し, 注入電流 $70 \mathrm{~mA}$ にて $P_{\text {out }}=10 \mathrm{~mW}$ となった。これまでの 報告(例えば14,15) $)$ と比較して高い出力が得られた。この時, $f_{\mathrm{r}}=3.6 \mathrm{GHz}$ であり, $2.5 \mathrm{Gbit} / \mathrm{s}$ の直接変調が可能である.

\section{2 光スペクトラム}

注入電流 $50 \mathrm{~mA}$, 温度 $25^{\circ} \mathrm{C}$ に FGLを駆動した時の光スペ クトラムをFig.6に示す. 図は波長分解能 $0.1 \mathrm{~nm}$ の光スペク

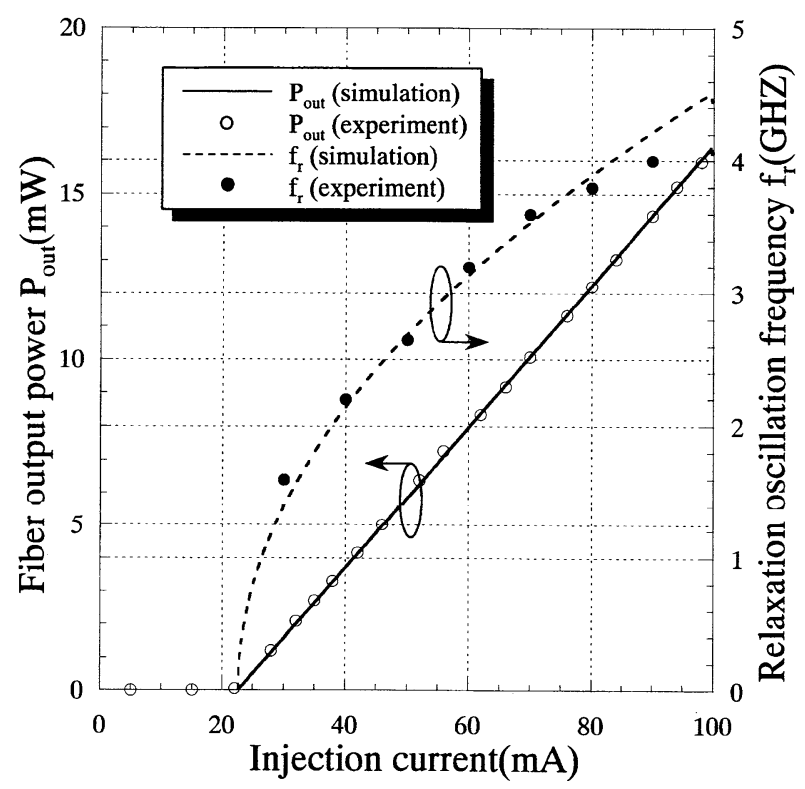

Fig.5 Simulated and experimental results of optical power and relaxation oscillation frequency as a function of injection current at temperature of $25{ }^{\circ} \mathrm{C}$.
トラムアナライザを用いて測定した結果である。単一縦 モード発振が観測され, サイドモード抑圧比 (SMSR: sidemode suppression ratio) は12.8dBである. 自己遅延へテロダ イン法により，波長分解能を小さくして観測した結果が

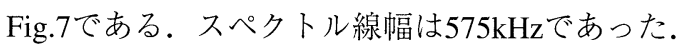

\section{3 杂隹音特性}

周波数に対する相対強度雑音 (RIN: relative intensity noise) 特性をFig.8に示す. 比較のために, 現在通信用光源 に用いられている定格出力 $4 \mathrm{~mW}$ の標準的な $1.55 \mu \mathrm{m} \mathrm{MQW}$ DFBレーザーの測定結果も示した. FGLの出力は $10 \mathrm{~mW}$, DFBレーザーの出力は $4 \mathrm{~mW} て ゙ あ る . ~ f_{\mathrm{r}}$ は, DFBレーザーでは 7.0GHz, FGLでは3.6GHzにあり, RINが大きくなっている. $2.5 \mathrm{Gbit} / \mathrm{s}$ 伝送の伝送帯域 0 ２GHzではFGLの方がRINは小さ い. 作製したFGLは雑音の点で優位な特性を有している.

\section{4 発振波長の温度特性}

モジュール内部のペルチェクーラを制御して温度を変 化させた場合の発振波長を測定した結果をFig.9に示す。

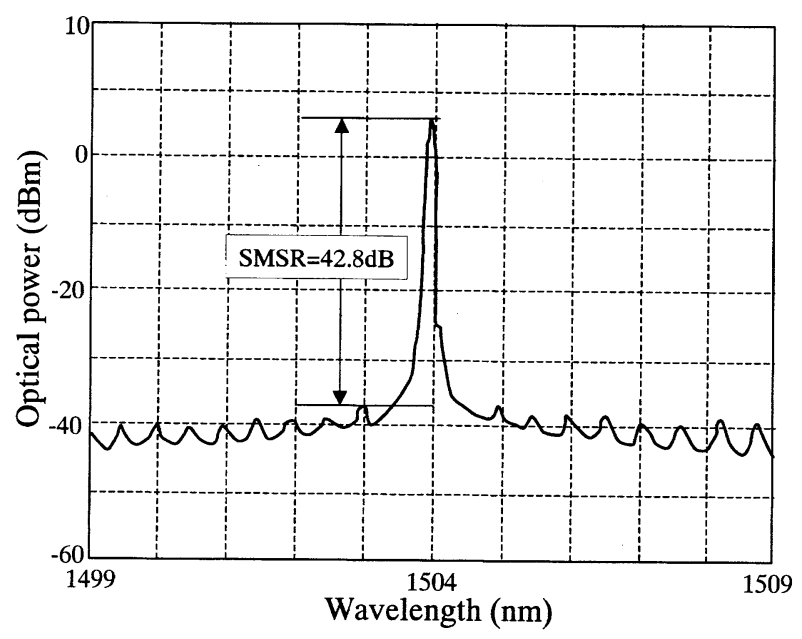

Fig.6 Optical spectrum at injection current of $50 \mathrm{~mA}$ at temperature of $25^{\circ} \mathrm{C}$.

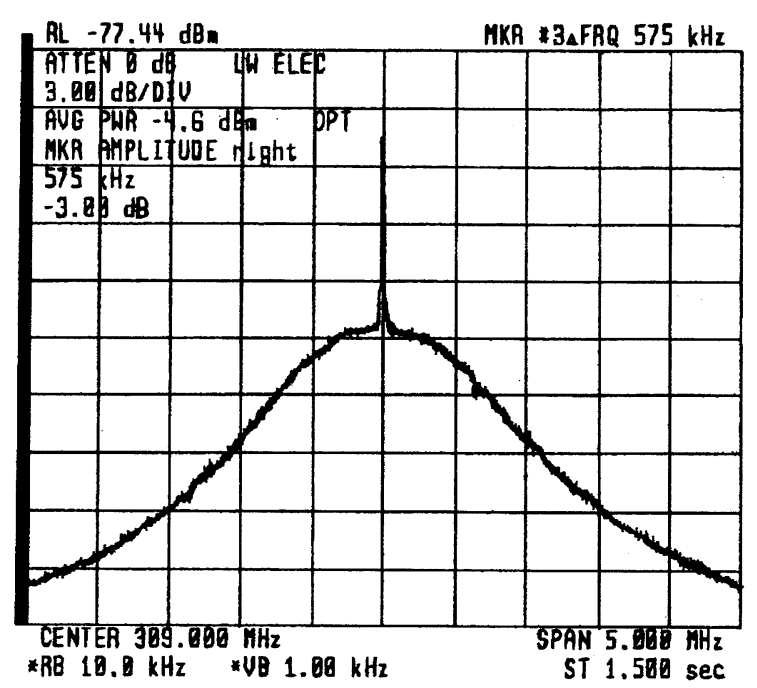

Fig.7 Spectral linewidth measured by self-delay heterodyne method. 


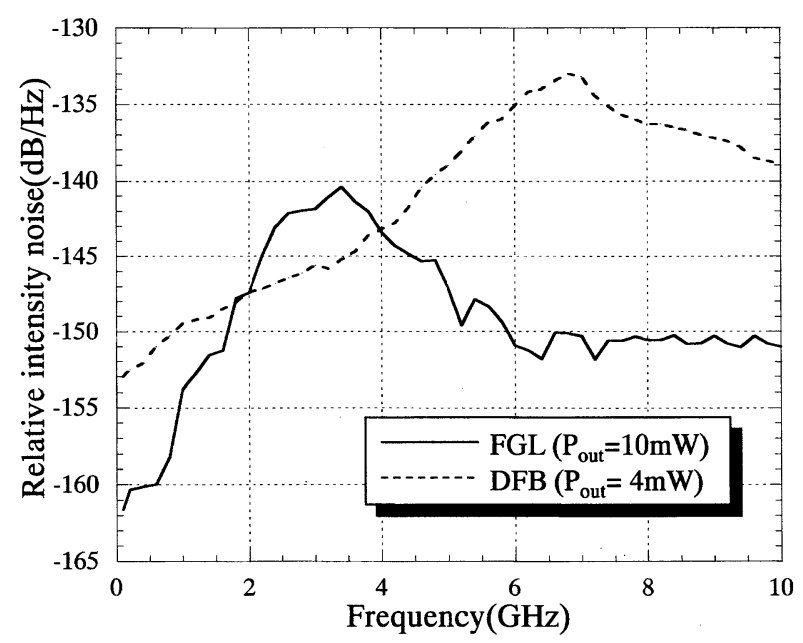

Fig. 8 Measured RIN as a function of frequency.

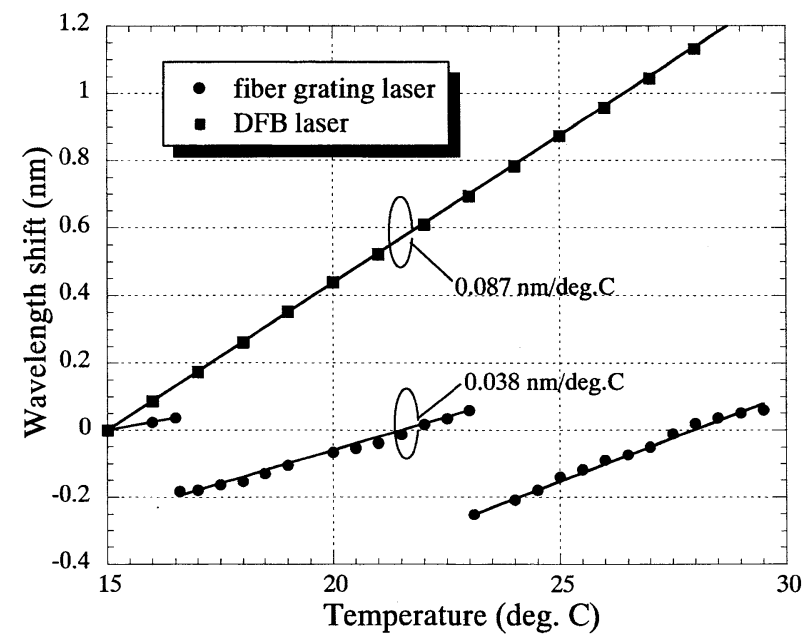

Fig.9 Temperature dependence of lasing wavelength.

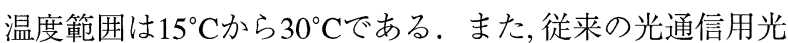
源と比較するために $1.55 \mu \mathrm{m}$ MQW DFBレーザーの測定結 果も示した。縦軸は, $15^{\circ} \mathrm{C} に$ 打りる発振波長を基準した波 長变化である。注入電流は一定にした。DFBレーザーは， $0.087 \mathrm{~nm} /{ }^{\circ} \mathrm{C}$ の温度依存性がある。これに対し, FGLは，

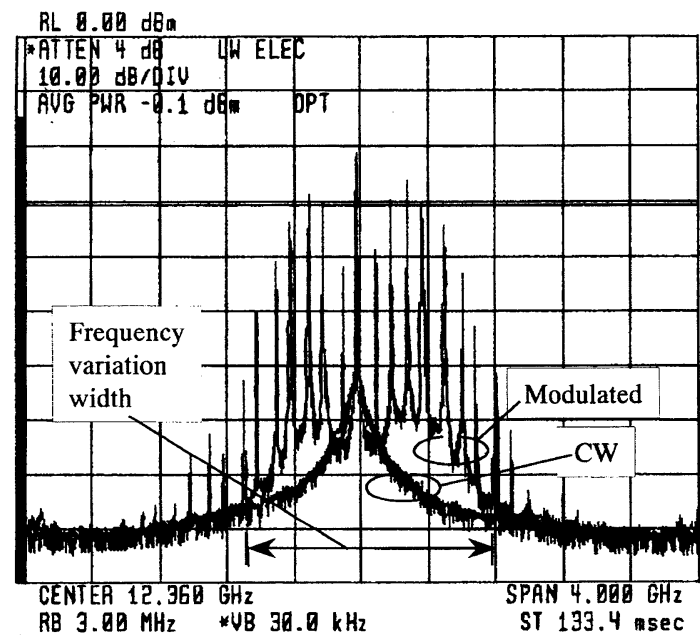

(a) fiber grating laser
$0.038 \mathrm{~nm} /{ }^{\circ} \mathrm{C}$ と, $1 / 2$ 未満である. 温度依存性は, FGLの方が 小さく,優れていることが判る. FGLでは, $23^{\circ} \mathrm{Cにてモード}$ ホッピングがあり, 連続的な波長变化をする温度範囲は, 約 $6{ }^{\circ} \mathrm{C}$ である，波長の变化幅は, 約 $0.25 \mathrm{~nm}$ である.

\section{5 周波数チャーピング}

FGLのチャーピング特性を把握するために, 線幅 $10 \mathrm{MHz}$

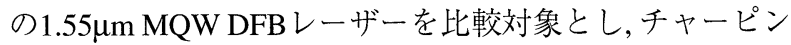
グスペクトラムを測定した. FGLの光出力を $10 \mathrm{~mW}, \mathrm{DFB}$ レーザーの光出力を $4 \mathrm{~mW}$ 一定とし, 周波数 $100 \mathrm{MHz}$ の正弦 波信号を各々のレーザーに直接入力して変調し, 出力され た変調光を線幅 $100 \mathrm{kHz}$ の波長可変光源のCW光と合波し て, 変調されたレーザーのチャーピングスペクトラムを得 た. 光変調度 (OMI: optical modulation index) が0.3の時の 測定結果をFig.10に示す。各々の図中には, 無变調時及び 変調時の測定結果が示されている．周波数変調成分が観 測出来る範囲を周波数変動幅と定義すると, FGLのチャー プ量は $48 \mathrm{MHz} / \mathrm{mA} ゙$ あ, DFBレーザーの $180 \mathrm{MHz} / \mathrm{mA}$ と比 較して顕著に小さい結果が得られた。

\section{6 伝送特性}

FGLの緩和振動周波数は $3 \mathrm{GHz}$ 以上を実現できており， $2.5 \mathrm{Gbit} / \mathrm{s}$ の直接変調は可能であるが, SOAの寄生容量及び パッケージの高周波対策が不完全であったため, FGLモ ジュールの変調带域は制限された。しかしながら, 伝送特 性を評価する上では, $1.55 \mu \mathrm{m}$ MQW DFBレーザーと同一の 条件において伝送を行うことによって, FGLの優位性を検 証することは出来る。そこで, $155 \mathrm{Mbit} / \mathrm{s}$ のRZ信号にて レーザーを直接変調し, 符号誤り率(BER: bit error rate)を 測定した結果をFig.11に示す．PRBSは223-1である．FGL とDFBレーザーを用いて, SMF (single mode fiber)を70km伝

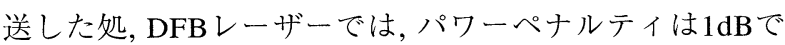
あった。これに対し, FGLでは0.3dBとなり, DFBレーザー の1/3未満であった．FGLは周波数チャーピングが少ない ため, 波長分散の影響を受けにくい。従って, 長距離の伝 送に優位である。

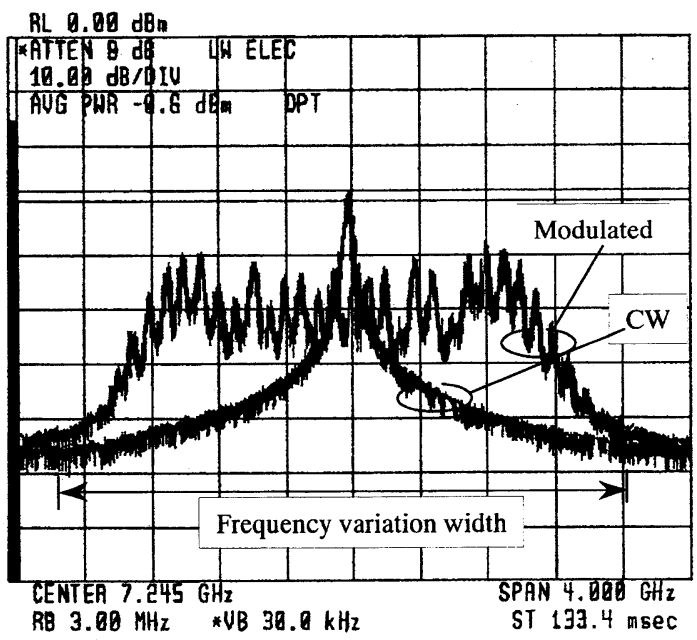

(b) DFB laser

Fig.10 Beat spectra for $\mathrm{CW}$ and directly modulated with $\mathrm{OMI}$ of 0.3 . 


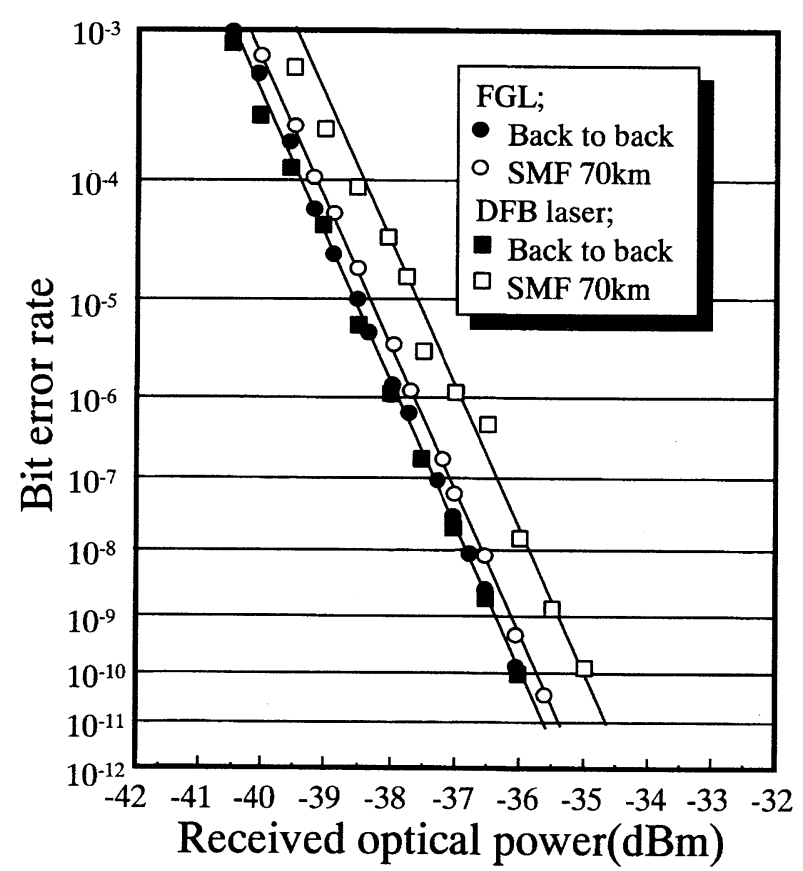

Fig.11 $155 \mathrm{Mbit} / \mathrm{s}$ BER performance with back to back and SMF $70 \mathrm{~km}$.

\section{5. まとめ}

FGLを作製するために, 共振器の複合反射面とレーザー の緩和振動周波数の観点から検討し, 特に長距離WDMシ ステムへ優位となる高出力かつ高速変調が可能なFGLの構 成を設計した，作製したFGLの光出力はこれまでの報告よ りも高い結果が得られ, かつ緩和振動周波数の測定結果か ら, $2.5 \mathrm{Gbit} / \mathrm{s}$ の直接変調が可能であると判った。

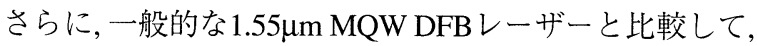
作製したFGLの通信用光源としての適用可能性を評価し た。その結果, 伝送帯域における雑音は, DFBレーザーよ り小さかった。また, 発振波長の温度依存性については, DFBレーザーと比較して $1 / 2$ 未満であった. FGLはモード ホッピングが生じる場合があるが, 線形に波長が移動する 温度範囲内にて温度を一定に保てばこれは生じない. FGL はFGのブラッグ波長にて発振波長を規定するのであるか ら, 所定の光出力にてブラッグ波長で発振するように温度 制御を行えば良い。
また, FGLは,一般的なDFBレーザーと比較して, 線幅が 狭く, チャーピングも狭い。実測したチャープ量はDFB レーザーと比較して1/3未満であった. 155Mbit/sのNRZ信 号を用いて, SMF70kmの伝送実験を行った結果, FGLのパ ワーペナルティはDFBレーザーの1/3未満となった. 従っ て, FGLは特に長距離の伝送システムに優位である。

謝 辞

FGL作製に御協力頂いた古河電気工業の粕川 秋彦主査, 入江 雄一郎氏, 三代川 純氏に, 有意義な討論をして頂いた 麦野明主任研究員, 橋詰 直樹氏に謝意を表しますととも に, 日頃御指導頂く神谷保チーム長に深謝致します。ま た, 日本大学理工学部の故中田順治教授への哀悼の意を表 するとともに,御指導に対し深謝致します.

\section{参考文献}

1) K. O. Hill, B. Malo, F. Bilodeau, D. C. Johnson, and J. Albert: Appl. Phys. Lett. 62 (1993) 1035.

2) B. Malo, J. Albert, K. O. Hill, F. Bilodeau, D. C. Johnson, and S. Theriault: Electron. Lett. 31 (1995) 879.

3) F. N. Timofeev, P. Bayvel, V. Mikhailov, P. Gambini, R. Wyatt, R. Kashyap, M. Robertson, R. J. Campbel, and J. E. Midwinter: Proc. OFC'97, ThM1 (1997) p.296.

4) F. N. Timofeev, P. Bayvel, J. E. Midwinter, R. Wyatt, R. Kashyap, and M. Robertson: Proc. ECOC'97, TU1A (1997) p.1.

5) R. Paoletti, M. Meliga, G. Rossi, M. Scofet, and L. Tallone: IEEE Photon. Technol. Lett. 10 (1998) 1691.

6) F. N. Timofeev, P. Bayvel, R. Wyatt, R. Kashyap, I. F. Lealman, and G. D. Maxwell: Proc. LEOS'98, FJ4 (1998) p.360.

7) R. F. Kazarinov and C. H. Henry: IEEE J. Quantum Electron. 23 (1987) 1401.

8) G. P. Agrawal and C. H. Henry: IEEE J. Quantum Electron. 24 (1988) 134.

9) J. Archambault and S. G. Grubb: IEEE J. Lightwave Technol. 15 (1997) 1378

10) F. Koyama, Y. Suematsu, S. Arai, and T. Tawee: IEEE J. Quantum. Electron. 19 (1983) 1042

11）那須 秀行, 大村 英之：レーザー研究 27 (1999) 51.

12) H. Nasu and H. Omura: Proc. LEOS'98, FJ2 (1998) p.356.

13) A. Kasukawa, T. Namegaya, N. Iwai, N. Yamanaka, Y. Ikegami, and N. Tsukiji: IEEE Photon. Technol. Lett. 6 (1994) 4.

14) P. A. Morton, V. Mizrahi, T. Tanbun-Ek, R. A. Logan, P. J. Lemaire, H. M. Presby, T. Erdogan, and S. L. Woodward: Appl. Phys. Lett. 64 (1994) 2634.

15) M. Ziari, A. Mathur, H. Jeon, I. Booth, and R. J. Lang: Proc. NFOEC'97 (1997) p.503. 